\section{Generational Lagging of Dignitaries, Main Cause of Technological Gaps in Community Leaders. Analysis of Generation $X$ and Boomers from the Technology Acceptance Model $^{1}$}

Research Hotbed Manjuy

Research Group Fénix

Manjuy Chairwoman Luz Briyid Contreras

Salamanca ${ }^{2}$

Manjuy Vice chairman Yon Garzón Ávila ${ }^{3}$

Universidad Nacional Abierta y a Distancia UNAD-

Facatativá, Colombia

Marzo de 2021

\section{ABSTRACT}

Community and neighborhood organizations are in the process of renewing the organizational culture, considering technological environments in the way of training, and advancing communally, being competitive in adaptation and learning, creating new solutions, promoting change, and altering the status quo, based on the advancement of technology over the last few years, currently applied in most organizations.

The decisive factor is the ability of true leaders to appropriate the Technological Acceptance Model -TAM- principles, participating in programs and projects, adopting new technologies from the different actors involved, contributing to the welfare of each community. There is, however, a relative resistance to the use of technology as support in community management, due to the generational differences in leaders and dignitaries, according to collected reports in this study, in relation to the age range of dignitaries -Generation X and Baby Boomers predominate-. They present a challenge to digital inclusion with difficulties related to age, cognitive, sensory, difficulty in developing skills, and abilities required in Digital Technologies, necessary to face new scenarios post-pandemic and, in general, the need to use technological facilities.

\section{KEYWORDS}

Digital Inclusion, Information and Communication Technologies -ICTs-, Digital Divide, Community Leadership, Technological Acceptance Model -TAM-

\footnotetext{
${ }^{2}$ Luz Briyid Contreras Salamanca. Public Accountant. Mail: luz.contreras@unad.edu.co

${ }^{3}$ Yon Garzón Ávila. Economist. Mail: yon.garzon@unad.edu.co
}

\footnotetext{
${ }^{1}$ This article is the result of a scientific research in the municipality of Facatativá, Colombia: Diagnosis of the Accounting Needs in Community Action Boards in the Municipality of Facatativá. Part of this work was included in a presentation in the International Prospecting Congress, UNAD, 2021.
} 


\section{INTRODUCCIÓN}

The objective of this working paper is to expound the causes of the generational lagging of community leaders from the Technology Acceptance Model -TAM- approach. Likewise, analyzing the different generations of dignitaries to understand the root of the problem of the apolitical behavior of the young people in the community. Additionally, showing the different alternatives proposed by public policies for the solution of the lagging problem.

Community and neighborhood organizations have shown a generational lagging in the use of new technologies, adoption, and adaptation to new technological environments, that would make it possible to advance towards solutions to community problems like handling information, the way of carrying accounting and how to streamline processes that benefit the surrounding community.

The generational lagging of dignitaries Generation X and Baby Boomers have political participation in the community, contrary to the little participation of the new generations-delays the technological updating of the organizations. The importance of information, management, use of varied and improved tools on different platforms, which are constantly evolving, do not include a setback in their applicability for public and private organizations.

The way users carry out the TAM, is a decisive factor in the appropriation of technologies. From the different factors that can objectively determine the use of technological system, within the users of the Community and neighborhood organizations, especially, in times of confinement due to Covid-19, where communication platforms and the technological tools for the application of projects are necessary for benefit of the community.

In this way, the TAM proposes that, given a stimulus to the adoption of technological tools such as accounting, the use of tools for group communication, in conjunction with the motivation of the user, leads to the effective use of the system. Nevertheless, the generation of dignitaries does not have the same facilities to react quickly to a stimulus.

Among the problems found in this study, are not only the problems of Generation X and Baby Boomer's lagging, and the disuse of technology in its optimal proportions, but also the young people community depoliticization looking for their future in academic preparation or seeking employment for individual benefit. In this way, generation $X$ and Boomers show resistance to change in terms of appropriate information, use of technologies for new procedures and application to calls, requiring the use of online platforms for the benefit of the community; in conjunction young people has some technologies abilities but they do not participate in community politics.

To counter these problems, public policies provide support to the leaders in Generation X and Baby Boomers, in addition to seeking the participation of youth in community leadership processes. There is assistance to the technological resource's requirements, training, and participation techniques. In the same way, the Academy provides training to the community leaders, pressuring the inclusion of the new generations to community leadership, and current dignitaries to update their knowledge in the use of technology, application of equipment and platforms that facilitate communication and use of digital resources

\section{CONTENT}

\section{Technological Acceptance Model -TAM-}

The TAM model is one of the most used tools to understand the causes of behavior in the adoption of technology by users. (Tavera, J. \& Arias, J., 2012). Davis (1989) initially proposed this model, explaining it is necessary a stimulus to the use of the new tool plus the motivation of the user, causing finally a response. (Illustration 1). 


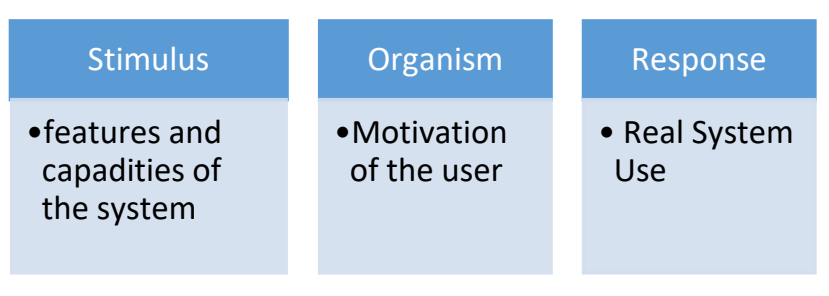

Illustration 1. Davis Model. Based on Córdoba, C. (2013).

The purpose of the TAM is to explain the causes of acceptance of technologies by users. This model proposes that perceptions of the individuals regarding the perceived usefulness and ease of use of an information system are conclusive in determining their intention to use a system. (Yong, J., et al., 2010). Determining the reasons that leaders of community organizations do not have the facilities other younger generations may have, there are educational reasons due to the type of training given to these new generations. Thus, the usefulness of technological aids is not greater than those facilities. Then the model predicts a low technological acceptance of the technologies of community organizations in several generations.

\section{Generational Differences}

Next, a general characterization of the main generations will be given, to analyze their implication in participation in neighborhood and community leadership scenarios (ICEMD, 2017).

The Silent Generation: They were born before 1946; also known as the builders, are currently between 74 and 93 years old. They are the silent generation because they did not participate in protests and fight for their dreams and achievement of goals. They know how to adapt to new times, are mobile phone users, just to communicate with children, grandchildren, and friends, avoiding isolation and loneliness. In the last year, the use of smartphones has almost doubled, among Silent Generation, from $8 \%$ to 15\%. (San Juan, J. 2018).

Boomers: They were born between 1946 and 1964 and are now between 56 and 74 years old. They are known as "digital immigrants", needing more time to adapt to digital dynamics.
(López, 2012). Community leaders are found largely in this generation.

Generation X (Baby Bust): They were born between 1965 and 1976 and are between 44 and 55 years old. They are the predominant generation in this study for municipality of Facatativá (Contreras, B. \& Garzón, Y. 2019). They do not require the internet to live daily and are adverse to the change. However, at the digital level, this learning occurs consciously and unconsciously, even when people and organizations are not very willing to learn. Precisely, from these obstacles in aversion to change, learning is also generated

Generation Y (Millennials): They were born between 1977 and 1997, are young people between 20 and 35 years old, also known as the "selfie" generation (La Vanguardia, 2017). They prefer to work for passion, regardless of sacrificing money. In a digital environment, they are the millennials and the most connected generation, however, they are classified as non-controversial and resigned.

\section{Community and Neighborhoods}

\section{Leadership}

Community leadership has contributed to the political development of the territories through their organization, to lead and promote community processes and provide solutions to problems in neighborhoods and rural areas, materializing through citizen participation -regulated, in Colombia, by Law 743 of 2002- playing a key role in society. Community leadership (Law 743 of 2002) is an organized, autonomous, and supportive social expression of civil society, promoting an integral, sustainable, and sustainable development, built from the exercise of participatory democracy in the management of community development.

Community organizations, formal neighborhood organizations, are constituted -in Colombia at least- by a natural person with a 
minimum of 14 years old ${ }^{4}$ residing in the territory. Within the framework of its objectives and principles, it is evident they face challenges in the use of digital tools such as computer programs, web platforms, digital tools and so on.

Community organizations seek neighborhood well-being, taking specific measures on this issue, on technological advances that benefit them. For this reason, formal and informal educational preparation are the forms adopted for the interests of the wider community. For instance, Barrera, A. (2019) submits that community organizations have very limited knowledge in accounting -essential for management in a community, source of benefits in the speed of taking accounts, in the relevance and in the ease of keeping the records.

Clavijo, J. \& Jiménez, J. (2016), in an administrative research in community leadership, states that, from the management point of view, a lack of direction and support was observed in the respective controls that Government must check regularly. The community organizations do not have the necessary orientation, training and strengthening. The training of the community organizations is often the responsibility of the government, and the training exists, but it is not effective due to the generational lagging mentioned.

On the other hand, if an analysis is made of the population that leads the communities, a relationship of generations can be established. Generations that do not have a clear and defined organization, in terms of higher education. Cortes, H., \& Peña, R. (2015) submits that they are without a clear and defined organization on the management of their resources because they do not have support in terms of training on their economy, staff, etcetera; and do not have the resources to provide financial support. Besides, it is the absence of strategies to obtain the resources, the lack of discipline for their administration; with the result that -although there is motivation to seek support plans- it presents

\footnotetext{
${ }^{4}$ In practice, the participation in Community Organization is
}

considerable difficulties for the continuous support for the community.

The main difficulties that arise at the microlevel, in neighborhood and community organizations, are the deficient knowledge at managerial, accounting, and technological, combined with internal structures of community organizations that disperse the social base and the concentration of power in leaders with problems of representation that generate conflicts of interest (Sánchez, M., 2014). Thus, the dignitaries have a wider set of problems such as the lack of representation due to the new generations do not make contributions from their rejuvenated knowledge in different managerial and technological matters, for example, management tools of neighborhood and community organizations.

\section{Government and Community Work}

From the governmental levels, there is a mission of rapprochement through the lives transformation, communities' integration, and empowerment of the territory to promote their happiness (Government of Cundinamarca, 2019). These actions are carried out through governmental organizations in charge of generating and promoting the participatory, timely actions, supporting the formulation of sustainable, social, infrastructure, cultural and environmental projects. In the same vein, the community action policy implementation, the promotion of citizen participation, financing of citizen, community participatory projects, promotion of effective publiccommunity cooperation, and support the local level to solve the demands of the communities. For this purpose, it establishes mechanisms offered via the internet.

Currently, organizations develop their administrative, operational, and managerial processes via the internet, according to the newspaper El País (2018). Colombia, for example, has $96 \%$ of entities using the internet for the development of their activities and fulfillment of their functions. The development of mechanisms that facilitate interaction between citizens and

reduced to Boomers and $\mathrm{X}$ generations. 
administrations via the Internet has advanced considerably during the last decade in developed countries. This is evidenced in calls made by government entities regarding community participation, the use of technological tools and computer training, and the use of digital aids. An approach to this issue is the advanced Technologies, including cyber security, cloud computing, the internet of things, robotics, 3D printing, virtual reality, and big data.

One of the most profound changes in community organizations has been the search, through new approaches, for competitive advantages in a dynamic world, constantly changing and, above all, full of political, economic, and technological uncertainties. The most frequent leadership styles in neighborhood and community organizations are usually related to the president of the neighborhood organization, in charge of aligning all dignitaries to the aims of the community, through an organizational strategy. Leadership can mark progress or stagnation for the community they represent.

For all of the above reasons, the current situation is reached. A mixture of the knowledge of different generations as a result of several factors, such as the valuation to the human resources, as a source of differentiation and success; continuous technological innovations and the resistance to change; sociodemographic factors (level of education); age-related difficulties (cognitive, sensory, motor).

\section{METHODOLOGY}

In Facatativá city, there are 110 neighborhood and community organizations formally associated with the government. They carry out activities of a different nature in terms of technical assistance, outreach events, calls for works in the neighborhoods, etc. Methodologically, the technological characteristics of community organizations are quantitative and qualitative described, using description and data in the same research; because all forms of data collection have their limitations, the use of a mixed design can minimize and even neutralize some of the disadvantages of certain fixed methods. (Sampieri \& Mendoza, 2005, p. 550).

In qualitative terms, a description of the generational characteristics of the dignitaries was made. Technological conditions according to the TAM model, in age ranges, through interviews to special groups of interest for the research, such as the local government, the presidents of the formal neighborhood and community organizations, their accountants, and the community.

On the other hand, the quantitative characteristic is in the measurements of the variables and statistical inferences regarding the data obtained in the measurement of the sample, with the purpose to make a description of the problem of the technological gap from the different generations of dignitaries.

The primary sources used are interviews with interest groups, presidents, accountants, etc., and surveys of the population sample (86 organizations). Regarding secondary sources, the cases of other community organizations in Colombia, and scientific articles, Laws, Regulations, Decrees, etc., have been studied.

However, data collection instruments such as surveys and interviews are indeed; the main instrument is the Technology Acceptance Model TAM- where a series of hypotheses are established in the behavior of the leaders of neighborhood and community organizations:

- Hypothesis 1: The Perceived Ease of Use influences the Perceived Usefulness

- $\quad$ Hypothesis 2: The Perceived Ease of Use influences the Attitudes toward Usability

- $\quad$ Hypothesis 3: The Perceived Usefulness influences the Attitudes toward Usability

- $\quad$ Hypothesis 4: The Perceived Usefulness influences the Intention to Use

- $\quad$ Hypothesis 5: The Attitudes toward Usability influences the Intention to Use

In order to facilitate the understanding of Model, the Illustration 2 represents the Hypotheses. 


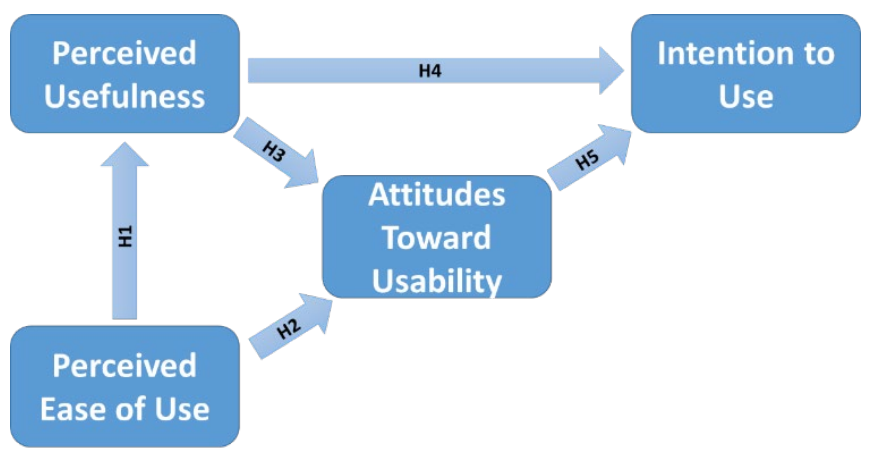

Illustration 2. TAM Model, Hypotheses. Elaborated by authors based on Davis et al. (1989).

It is possible to verify, in the identification of the hypotheses, that the leaders of the neighborhood organizations have a problem in the generational gap that makes it impossible to use technological tools that facilitate the tasks and progress of their organizations. In this way, in Hypotheses 1 and 2, it is stated about the Perceived Ease of Use -the main problem of the generations $X$ and Bloomers of leaders- affects the Perceived Usefulness and Attitude towards Usability. Thus, the system is threatened, in effect, in the Intention to Use technological tools.

\section{MAIN RESULTS}

Given the technological, computer, and communication development of the world, the population has been forced to acquire, at different levels, the skills of a digital world. The generations have followed their history of learning that passes rapidly etween technological advances, new forms of communication, and the use of data in different tools or applications. These generations do not adapt to the same rate of learning. Newer generations have the advantage of a technological world from birth, schooling, and daily use, while older generations do not adapt or do not have the facilities in a changing world with rising advances.

The problem lies in the leaderships within community organizations where the majority of dignitaries belong to lagging generations such as Generation X or Baby Boomers, where their economic activity is pensioners and freelancers. While the new generations are not interested in communal politics but in their life projects, busy in their academic training or seeking work to support their families. In this way, the panorama moves between the generations with few technological skills that face the changing world in terms of community participation, and the new generations maintain reserve due to their occupations and preferences.

From the TAM, with the hypotheses raised (Illustration 3), it is possible to conclude that the leaders of neighborhood and community organizations have a generational gap that makes it difficult to use technological tools that facilitate the tasks and progress of community organizations.

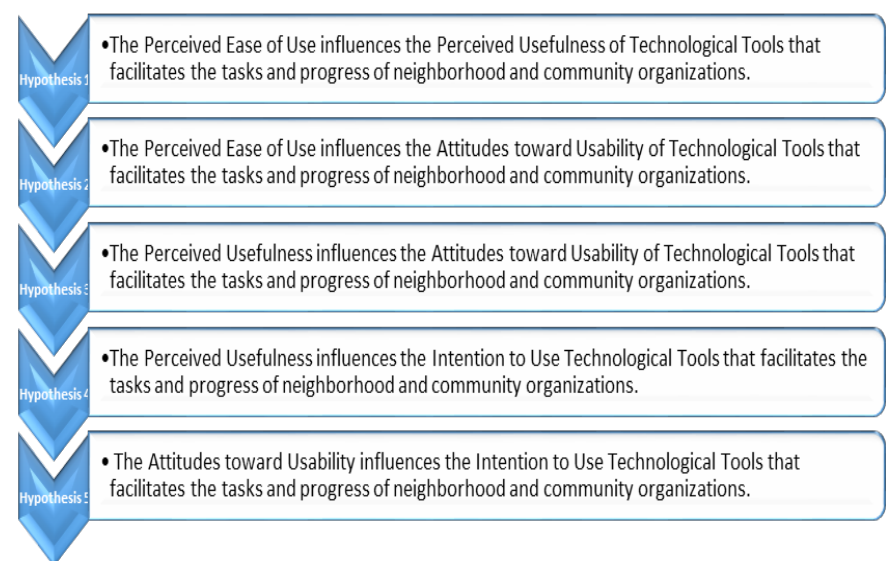

Illustration 3. Hypotheses. TAM Model adapted for Formal Neighborhood and Community Organizations. Based on the original model, Davis et al. (1989).

Hypothesis 1 shows the perceived ease-ofuse influences the perceived usefulness of technological tools. In Hypotheses 2 and 3, it is stated the perceived ease of use (the main problem of the generations of leaders) and the perceived usefulness affect the attitudes toward usability of technological tools. The system is threatened in the intention of using technological tools, via hypotheses 4 and 5 . Indeed, subjectively, generation $\mathrm{X}$ and boomers dignitaries show a tendency to the difficulty to use technological tools.

Emphasizing, the TAM provides important information about the difficulty for the adoption of technologies in community organizations, because of the difficulty they are faced. Even further, regarding the perception of the usefulness of the technologies adapted to community organizations for accounting, communication, and general use of the web, they perceived them highly important, but 
younger people consider them more important than the older generation consider them.

Regarding the effective use of these tools (accounting, communication, and network), Generation $X$ and Boomers use them due to the ease of use, but not due to the usefulness.

Finally, the dignitaries (in Generations $X$ and Boomer) are willing to accelerate the nonformal training process, thus completing the TAM cycle, showing that the attitude towards the use of computer tools is a good sign, but the lag generational may be stronger, which could delay the process of effective use of technologies for the benefit of community organizations.

\section{DISCUSSION AND PROPOSAL}

Although, there is resistance to change because of the historical generation and the way the new generations do not participate in community and neighborhood leadership. Within the framework of community organizations, there are government organizations, non-governmental and universities, which entail training, providing tools to the leaders of community organizations to close the technological gap.

Formal education institutions approach the solution from the opening of technological, professional, and postgraduate programs, to train the community leaders. For example, the professional programs of business administration, accounting and economics; educating in community leadership, but also the administration of public and private entities, resources, planning, and execution of community projects.

For its part, the government, through institutions close to the community, focuses on encouraging young people to participate in the presidencies of the community organizations. Thus, the problem cannot only be seen in terms of the interest of the new generations, but it is necessary for the professional formation and neighborhood leadership trajectory.

Government campaigns to promote the participation of new generations through calls for young leaders to participate in volunteering abroad are promoted (IDACO. 2019). In the same way, the formation of new technologies is carried out to reduce the digital knowledge gaps that exist intergenerationally (IDACO, 2015).

\section{CONCLUSIONS}

Technological advances lead organizations to work within the best tools available. Although the neighborhood and community organizations are not-for-profit organizations, they are not competing; they must use technological applications in order to advance in the community to achieve the targets, given the resistance to change by Generation $X$ and Baby Boomers, a majority in the leaderships of the formal neighborhood organizations.

It is decisive, in the community environment, the appropriation of the TAM for the interpretation and solution of the generational lagging. Nevertheless, it is necessary to attack the problem from the generation gap and not only from the technological lagging of the generations of dignitaries. In order to focus on local problems for competitiveness among community organizations that lead to profit the entire community.

Efforts made by government entities in assisting community neighborhood organizations, with training, promoting participation and encouraging updating, are necessary. In addition to the permanent pressure to include the new generations to the community and neighborhood leadership, plus training current dignitaries in technology, applications, and platforms for the benefit of the communities. Just as the effort of educational institutions is necessary, in the formation of administrative leaders.

Finally, it is crucial to understand that the solutions imply evolution in the different capacities of the dignitaries, which contributes to the achievement of the commitments and to improvements for the formal neighborhood organizations. 


\section{BIBLIOGRAPHIC REFERENCES}

Barrera, A. (2019). Conocimientos de gestión contable y financiera de los dignatarios de las juntas de acción comunal de Sogamoso. Libros Universidad Nacional Abierta y a Distancia.

https://doi.org/10.22490/9789586516389.13

Clavijo, J. \& Jiménez, J. (2016). Evaluación de la gestión administrativa de dignatarios de la junta de acción comunal, barrio Américas Occidental, período 2012-2016.

Colombian Congress. (2002) Ley 743 (2002). Desarrollo del Artículo 38 de la Constitución Política de Colombia en lo Referente a los Organismos de Acción Comunal. Ministry of the Interior. Bogota.

Contreras, B. \& Garzón, Y. 2019. Diagnóstico para el Reconocimiento de las Necesidades Contables de las Juntas de Acción Comunal del Municipio de Facatativá, Cundinamarca. Group of Research Fénix. Universidad Nacional Abierta y a Distancia. Facatativá.

Córdoba, C. (2013). La experiencia de usuario extendida (UxE): un modelo teórico sobre la aceptación tecnológica y un estudio de caso en entornos virtuales de aprendizaje. Universitat Politècnica de Catalunya.

Cortes, H., \& Peña, R. (2015). Plan de asesoría y capacitación en contabilidad y administración para el adulto mayor de la junta de acción comunal del barrio Antonio Granados ubicado en la localidad de Suba de la ciudad de Bogotá. Retrieved from https://ciencia.lasalle.edu.co/contaduria_publica /292

Davis, F. (1989). Perceived Usefulness, Perceived Ease of Use, and User Acceptance of Information Technology. MIS Quarterly, 13(3), 319-340. Doi:10.2307/249008.

Davis, F., Bagozzi, R., \& Warshaw, P. (1989). User Acceptance of Computer Technology: A comparisson of two theoretical models. Management Science, Vol. 35, No. 8, pp. 982.

El País, Colombia (2018). El 96 \% de las Empresas en Colombia Utilizan Internet. Colprensa, El País. Cali. Accessed on 8 March 2021. Retrieved from https://cutt.ly/VfPPEWj

Government of Cundinamarca (2019). Jóvenes Líderes Comunales Realizarán Voluntariado en México.
Noticias Gobernación. Accessed on 8 March 2021. Retrieved from https://cutt.ly/NfPPsDq

ICEMD (2017). Las 6 Generaciones de la Era Digital. Instituto Economía Digital. Madrid. Accessed on 9 march 2021. Retrieved from https://cutt.ly/ZfPPF90

IDACO (2015). Líderes Comunales se Capacitan en Nuevas Tecnologías. Noticias IDACO. Accessed on 10 March 2021. Retrieved from https://cutt.ly/AfOay40

La Vanguardia, (2017). Hacemos un Selfie a la Generación Z. La Vanguardia, Jóvenes y Tecnología. Accessed on 15 de March 2021. Retrieved from https://cutt.ly/azVs65h.

López, R. (2012). Prevención y Menores en las TIC. Del Control al Empoderamiento. Universidad Nacional de Educación a Distancia. Madrid. Accessed on 15 March 2021. Retrieved from https://cutt.ly/3zVawOy.

Sampieri \& Mendoza (2005). Los métodos mixtos: ¿el fin de la "guerra" entre la investigación cuantitativa y la investigación cualitativa. UNE, Cantuta-Chosica.

San Juan, J. (2018). Las Seis Generaciones Digitales que Conviven Hoy Día en Nuestra Sociedad. TeknLife. Accessed on 15 March 2021. Retrieved from https://cutt.ly/OfPPV0p

Sánchez, M. (2014). Lineamientos estratégicos para las juntas de acción comunal en Barranquilla, Colombia; Strategic guidelines for community action boards in Barranquilla, Colombia.

Tavera, J, \& Arias, J. (2012). Mobile Internet: Technologic acceptation for the digital gap closing in Colombia. Perfil de Coyuntura Económica, (19), 139-155. Accessed on 10 March 2021. Retrieved from https://n9.cl/pkq4k.

Yong, L, Rivas, L., \& Chaparro, J. (2010) Modelo de acepción tecnológica (TAM): un estudio de la influencia de la cultura nacional y del perfil de usuario en el uso de las TIC. Innovar 20(36), 187-204. 